\title{
Perception of English Learning Based on Local Wisdom for Junior High School Students in Desa Kolam Deli Serdang District North Sumatera Indonesia
}

\author{
Indah Sari ${ }^{1}$, Hanifah Mutia ZN. Amrul ${ }^{2}$ \\ 1,2Universitas Pembangunan Panca Budi, Indonesia \\ Email: indah.sari877@gmail.com
}

\begin{abstract}
Integrating local wisdom in the context of English learning is very important regarding to the culture maintenance. Learning English as a foreign language has two kinds of motivation namely instrumental and integrative. This study applied qualitative design by administrating the questionnaires to two teachers and 20 students. The results showed that the teachers had not integrated the local wisdom optimally and tended to apply the systemic knowledge in English teaching rather than the schematic knowledge. However, both of them showed their positive responses in relation to integrate the local wisdom in the teaching materials. Furthermore, most students showed their positive responses regarding to integrate local wisdom into English materials in order to maintain and protect their local wisdom and tradition.
\end{abstract}

Keywords: learning; English; local wisdom

\section{Introduction}

Learning refers to a relatively permanent change in behavior those results from experience. This definition of learning has two important components. First, it reflects change in the potential for a behavior; it does not automatically lead to a change in behavior. People must be sufficiently motivated to translate learning into behavior. Second, the behavior changes that it causes are not always permanent. As a result of new experiences, previously learned behavior may no longer be exhibited. For example, you may learn a new and faster route to work and no longer take the old route. Also, we sometimes forget a previously learned behavior, and therefore are no longer able to exhibit that behavior. Forgetting the story line of a movie is one instance of the transient aspect of learning.

Moreover, it involves acquiring and modifying knowledge, skills, strategies, beliefs, attitudes, and behaviors (Schunk, 2012). People learn cognitive, linguistic, motor, and social skills, and these can take many forms. At a simple level, children learn to solve math question or to recognize $y$ in the word $d a d d y$, to tie their shoes, and to play with other children. At a more complex level, students learn to solve long-division problems, write term papers, ride a bicycle, and work cooperatively on a group project.

In relation to learning, there are three classifications such as 1) learning involves change, 2) learning endures time, and 3) learning occurs through experiences. One criterion is that learning involves change in behavior or in the capacity for behavior that people learn when they become capable of doing something differently. At the same time, people must remember that learning is inferential. They do not observe learning directly but rather its products or outcomes. Besides that, learning is assessed based on what people say, write, and do. But they also add that it involves a changed capacity to behave in a given fashion because it is not uncommon for 
people to learn skills, knowledge, beliefs, or behaviors without demonstrating them at the time learning occurs.

A second criterion is that it endures over time which excludes temporary behavioral changes (e.g., slurred speech) brought about by such factors as drugs, alcohol, and fatigue. Such changes are temporary because when the cause is removed, the behavior returns to its original state. But learning may not last forever because forgetting occurs. It is debatable how long changes must last to be classified as learned, but most people agree that changes of brief duration (e.g., a few seconds) do not qualify as learning.

A third criterion is that it occurs through experience (e.g., practice, observation of others). This criterion excludes behavioral changes that are primarily determined by heredity, such as maturational changes in children (e.g., crawling, standing). Nonetheless, the distinction between maturation and learning often is not clear-cut. People may be genetically predisposed to act in given ways, but the actual development of the particular behaviors depends on the environment. Language offers a good example. As the human vocal apparatus matures, it becomes able to produce language; but the actual words produced are learned from interactions with others. Although genetics are critical for children's language acquisition, teaching and social interactions with parents, teachers, and peers exert a strong influence on children's language achievements. Students who have never been taught the prerequisite social skills which encompass communicating, trust building, leadership, conflict resolution, group management, giving and receiving feedback, active listening skills, etc. cannot be expected to work together effectively (Johnson in Ali, 2019).

In line with learning, English is learned by people around the world and has increased. Then, the increased learning and teaching of English throughout the world during recent years in both state and commercial educational institutions has produced a new cadre of professionals: teachers of EFL. Some have moved across from teaching English as a mother tongue, others from teaching modern languages; many have been drawn into service for no other reason than that their own spoken English is good, or perhaps because they are native English speakers. English in Indonesia is still a foreign language that is, it is taught in schools, often widely, but it does not play an essential role in national or social life.

\section{Review of Literatures}

\subsection{English as a Foreign Language}

Brumfit, Flavell, Hill and Pincas (1980) classify two main kinds of motivation in foreign language learning: instrumental and integrative. When anyone learns a foreign language instrumentally, he needs it for operational purposes to be able to read books in the new language, to be able to communicate with other speakers of that language. The tourist, the salesman, the science students are clearly motivated to learn English instrumentally. When anyone learns a foreign language for integrative purposes, he is trying to identify much more closely with a speech community which uses that language variety; he wants to feel at home in it, he tries to understand the attitudes and the world view of that community. Foreign speakers who learn cultural aspects can take advantage of these cultural insights as a provision for their life in Indonesia. The cultural aspect supports foreign speakers in speaking Indonesian according to the situation and condition of Indonesian 1602 society. In addition, introducing Indonesian culture to foreign speakers can also foster a positive and appreciative attitude for foreign speakers towards the richness of Indonesian culture (Tanwin, 2020). 
People will see their perspective and recognize that there are other ways of saying things, other ways of thinking, and other patterns of emphasis by learning a foreign language. Inextricably bound with a language and for English, with each world variety are the cultural patterns of its speech community. English, by its composition, embodies certain ways of thinking about time, space and quantity; embodies attitudes towards animals, sport, the sea, relations between the sexes; embodies a generalized English speakers' world view. Teachers must be more creative in developing learning materials to be more interesting and favoured by students (Darmuki in Nurlina, 2020).

People face the world from a slightly different standpoint and structure it in slightly different conceptual patterns by operating in a foreign language. Some of the educational effects of foreign language learning are achieved albeit subconsciously in the first months of study, though obviously a 'feel' for the new language, together with the subtle impacts on the learner's perceptual, aesthetic and affective development, is a function of the growing experience of its written and spoken forms. Clearly the broader aims behind foreign language teaching are rarely something of which the learner is aware and fashionable demands for learner-selected goals are not without danger to the fundamental processes of education.

Learning is a process of changing human life for the better. As from the state of not knowing to knowing, not being able to be, and not understanding becoming understanding. The most visible changes when someone has learned is in their behavior. Gagne (in Slameto 2010: 13) argues that, the definition of learning is the modification or reinforcement of behavior through experience and the process of changing individual behavior through interaction with the environment. According to Pribadi (2009: 18) the purpose of learning is a description of general competences and specific competencies, which will help the teacher or instructor direct the student learning process. By knowing the learning objectives, students will be motivated in carrying out the learning process in an effort to achieve the expected competencies. Language learning carried out in schools is not only focused on learning the main language, namely Indonesian, but also learning in the second language (Harahap, 2020). Learning a second language occurs in association with the community. This is in accordance with the opinion of Iskandarwassid (2009: 79) which states that learning a second language occurs in multilingual communities, namely when students must start learning a second language to be able to communicate between regions, between provinces, or in the community. In this event the need arises for teaching a second language to take place and what techniques are suitable for use. The second language taught in schools other than regional languages, also includes foreign languages. According to the linguistic dictionary, Kridalaksana (2001: 21) foreign languages are languages that are mastered by linguists who usually through formal education sociocultural are not considered their own language. Foreign languages taught such as English, French, Arabic, Japanese and German.

\subsection{English Learning Based on Local Wisdom}

In learning English, the culture of native countries must be maintained very carefully therefore the identity and integrity reflected in their characters as well as their spirit nationalism (Septi 2016). Then, the management of English language teaching that should be on supervised by professional and skilled teachers who take the consideration in promoting local wisdom. Moreover, language learning especially English consists of basic principles of life that are socioculturally transferred through some socio-cultural values and norms used as guidelines in daily life. (Diaz-Rico, 2004). In relation to the socio-cultural, culture involves belief and values, rhymes, rules, and roles in which it has explicit and implicit patterns for living, the dynamic system of commonly agreed-on symbols and meaning, knowledge, belief, art, morals, law, 
customs, behaviors, traditions, and/or habits shared and make up the total way of life in constructing a personal identity.

In addition, it can be interpreted that local wisdom is as local ideas that contain wise, prudent, good value that is believed and obeyed by the members of the community (Kun, 2013). Then, it is a view of life and science as well as a variety of life strategies in the form of activities carried out by local communities in answering various problems regarding their needs. Then, English materials used in learning not only apply books from the government, but teachers can also develop teaching materials based on local wisdom.

In relation English learning, there are two domains of knowledge namely systemic knowledge and schematic. Hedge (2008) points out that the schematic knowledge is out of linguistics aspects which contains socio cultural knowledge, domain knowledge genre knowledge general knowledge. Margana (2009) describes that English teachers tend to implement the systemic knowledge rather than schematic knowledge. However, they must integrate the local wisdom in their material teachings in terms of having the students be proud of their local wisdoms.

The integration of two cultures will sharpen the learners' understanding of second language therefore they are able to use language in cultural context appropriately. The choice of English learning based on the culture will assist the learners to comprehend L2 regarding to the authentic and real life condition (Peterson and Coltrane, 2003).

\section{Research Methods}

This study applied descriptive qualitative design by giving the questionnaires to the teachers and the students. The subjects of this study were two English teachers and 20 students. The technique of data analysis used Miles, Huberman, and Saldana steps (2014) which consists of data condensation, data display and data verification. According to the Richie in Moleong in Pandapotan (2020) explains that qualitative method is an effort to serve the social world and its perspective in a world, from the concept of point of view, behaviorism, perception, and matters of human researched.

\section{Discussion}

Based on the data analysis, it figured out that the teachers used the systemic knowledge rather than schematic one. This indicated that they had not integrated the local wisdom optimally but they responded in a positive way of integrating local wisdom in the teaching materials. Meanwhile, the students gave the positive responses in terms of integrating the local wisdom in the learning material as an effort to maintain and protect their own tradition and culture. Related to the local wisdom that must be maintained in Desa Kolam and implemented in English learning were: 1) praying before starting the lessons, 2) Helping friends in memorizing the vocabulary, 3) working together or collaborating in group, 4) having role play in conversation topic, 5) giving rewards to the students in their outstanding achievement, and 6) integrating local wisdom in the learning material. This section focused mainly on reviewing the studies that discussed the importance of pragmatics in developing second and foreign language. This probably was the result of generations of learners of English language who completed their studies in the foreign language with a relatively good general language proficiency but weaker skills to interpret the messages and intentions that are conveyed in conversations, correctly. This 
particular competence is referred to as pragmatic competence. Findings showed that pragmatic 1067 competence should be developed through explicit and implicit instruction, with the prevalence of the former, with a range of activities and situations/contexts. Especially the rules of social norms that are different from the ones in the learners' native cultures should be given emphasis. After all, communication is not a mere exchange of messages, but it also is correct and appropriate interpretation of intentions on both sides and being able to respond accordingly (Ibrahim, 2020).

\section{Conclusion}

It can be concluded that the local wisdom in Desa Kolam consists of 1) helping each other 2) working together, 3) Procedural activities, 4) Giving reward, and 5) Being grateful. These should be integrated into English material at schools. Unfortunately, teachers have not integrated these optimally since they focus on the systemic knowledge rather than schematic knowledge such as local wisdom.

\section{References}

Ali, W.T. (2019). Effects of Cooperative Learning Method (CLM) on Vocabularies and Grammars in Essay Writing. Budapest International Research and Critics in Linguistics and Education (BirLE) Journal Vol 2 (1): 1-11.

Broughton, G., C. Brumfit., R. Flavell., P. Hill., and A. Pincas. 1980. Teaching English as a Foreign Language Second Edition. London: Routledge

Diaz-Rico, L.T. 2004. Teaching English Learners: Strategies and Methods. Boston: Pearson Education Inc.

Harahap, H.J.S.P. (2020). The Importance of German Language Skills in the Tourism Sector. Britain International of Linguistics, Arts and Education (BIoLAE) Journal Vol. 2 (3): $817-824$.

Hedge, T. (2008) Teaching and Learning in The Language Classroom. New York: Oxford University Press

Ibrahim, A., and Maniam, M. (2020). A Review Article of the Pragmatics-Based-Curriculum in EFL Context: Focus on the Curriculum in Iraq. Budapest International Research and Critics in Linguistics and Education (BirLE) Journal Vol 3 (2): 1065-1073.

Iskandarwassid. 2009. Strategi Pembelajaran Bahasa. Yogyakarta: PT. Remaja Rosdakarya.

Kridalaksana, Harimurti. 2001. Kamus Linguistik (edisi ketiga). Jakarta: Gramedia.

Margana. 2009. Integrating local culture into English Teaching and Learning process. Linguistik dan Sastra, vol 21, no.2

Miles, M. B., A.M., Huberman, \& J. Saldana2014. Qualitative Data Analysis, A Methods Sourcebook Edition 3. USA: Sage Publications

Nurlina, L. (2020). The Ways to Develop Indonesian Learning Material Enriched by Local Culture for Foreign Students. Budapest International Research and Critics in Linguistics and Education (BirLE) Journal Vol 3 (2): 1045-1055.

Pandapotan, S. (2020). Descriptive Study: Cross-Nation Marriage Family between Foreign Citizen and Local Citizen in Timbang Jaya Village, Bahorok Sub-District, Langkat Regency. Budapest International Research and Critics Institute-Journal (BIRCI-Journal) Vol 3 (2): 1499-1505.

Peterson, E. \& Coltrane, B. (2003). 'Culture in Second Language Teaching'. [http:// www.cal.org/ resources /digest/0309peterson.html]

Prasetyo, Z. K.2013. Pembelajaran Sains Berbasis Kearifan Lokal. Seminar Nasional Fisika dan Pendidikan Fisika 
Pribadi, Benny A. 2009. Model Desain Sistem dalam Pembelajaran. Surakarta: Dian Rakyat.

Schunk,D. H. 2012. Learning Theories: An Educational Perspective Sixth Edition. Boston, USA: Pearson Education, Inc.

Septi, A. P. 2016. Managing Local Wisdom in English Teaching Materials. Proceedings of the Fourth International Seminar on English Language and Teaching (ISELT-4)

Slameto. 2010. Belajar \& Faktor-Faktor Yang Mempengaruhinya.Jakarta: Rineka Cipta.

Tanwin, S., and Rosliani. (2020). The Development of Indonesian Language Teaching Materials for Beginner Level of Foreign Speakers with Local Content. Budapest International Research and Critics in Linguistics and Education (BirLE) Journal Vol 3 (3): 1600 -1613. 